Edison Omollo Oduor', Josphat Igadwa Mwasiagi² , Fredrick Nzioka Mutua'

${ }^{1}$ Technical University of Kenya, P. O. Box 52428 (00200), Nairobi, Kenya

2School of Engineering, Moi University, P. O. Box 3900 (30100), Eldoret, Kenya

\title{
Preliminary Study regarding the Effects of Different Soil Treatments on the Strength of Canvas Material during the Soil Burial Test
}

\author{
Preliminarna raziskava učinkov različno obdelane zemlje \\ na trdnost platna med preskusom z zakopavanjem v zemljo
}

\author{
Original Scientific Article/Izvirni znanstveni članek \\ Received/Prispelo 06-2015 • Accepted/Sprejeto 10-2015
}

\begin{abstract}
The durabilities of textile materials, which during their usages come into direct contact with soil, have traditionally been measured using the soil burial test (BS 6085: 1992). Using the aforementioned standard, coated textile materials are normally buried under standard soil conditions for 28 days, while non-coated textiles for 14 days and the deterioration assessed. The duration of this test is too long and it discourages many business people and manufacturers, to whom urgency is the key and therefore opt to skip this test. This study investigated the effects of different soil treatments on the strengths of canvas materials during the soil burial test. By adding cow manure, chicken manure and potato peelings with the controlled addition of water, the changes were investigated in the strengths of the canvas materials buried in the soils. The results obtained during this research work indicated that the addition of water (in a controlled manner) can lead to a change of $10 \%$ to $90 \%$ in the strengths of the buried canvas materials, according to the different types of manure. When considering the different types of manures (with water additions) there were strength losses of $70 \%, 80 \%$ and $90 \%$ for non-cultivated soil, soil with cow dung, and soil with chicken manure respectively. Similar trends were also recorded for strength losses in the weft direction. A strength reduction factor which considered the reductions in strengths of the canvas materials exposed the different treated soils compared to the non-treated soil (without water), indicating that chicken manure (with the addition of water) can produce a strength reduction factor of 8.32, whilst the non-cultivated soils (with the addition of water) gave a strength reduction factor of 6.

Keywords: Soil burial test, canvas, microbial deterioration, soil cultivation
\end{abstract}

\section{Izvleček}

Trajnost tekstilnih materialov, ki med svojo uporabo pridejo v direktni stik zzemljo, se tradicionalno meri s pomočjo preskusa z zakopavanjem v zemljo (BS 6085: 1992). Skladno s Standardom BS 6085 so premazane tekstilije navadno zakopane v standardnih pogojih v zemljo 28 dni, medtem ko so nepremazane zakopane 14 dni, predno se ocenjuje poslabšanje. Poskus traja predolgo, kar posledično odvrača mnoge poslovneže in proizvajalce, za katere je hitrost ključnega pomena. Slednji zato pogosto preskočijo sam poskus. Raziskava preiskuje učinke različnih obdelav z zemljo na trdnost platna med preskusom z zakopavanjem v zemljo. Spremembe v trdnosti platna, ki je bilo zakopano v zemlji, so bile raziskovane z dodajanjem kravjega gnoja, kokošjega gnoja ter krompirjevih olupkov z nadzorovanim dodajanjem vode. Izsledki raziskave nakazujejo, da lahko nadzorovano dodajanje vode vodi v 10-90\% spremembo v trdnosti zakopanega platna, odvisno od vrste gnojila. Pri obravnavi različnih vrst gnojil (z vodnimi 
primesmi) je trdnost padla za 70 \%, 80 \% in 90 \% pri nekultivirani zemlji, zemlji s kravjim oziroma kokošjim gnojem. Podobni trendi so bili zabeleženi tudi za izgubo trdnosti v smeri votka. Faktor znižanja trdnosti, ki upošteva izgubo trdnosti platna, ki je bilo izpostavljeno različno obdelani zemlji v primerjavi z neobdelano zemljo (brez vode), nakazuje, da je faktor znižanja trdnosti pri kokošjem gnoju (z dodatkom vode) 8,32, medtem ko je pri nekultivirani zemlji ( $z$ dodatkom vode) 6.

Ključne besede: preskus z zakopavanjem v zemljo, platno, mikrobno poslabšanje, obdelovanje zemlje

\section{Introduction}

The soil burial test is performed for determining the resistances of textiles to microbiological deterioration. It is used as a method of determining the effectiveness of antimicrobial finishing on textiles. This test is usually considered as the most severe test for those textiles that during their usages come into direct contact with soil, for example tents, sandbags, tarpaulins, geotextiles etc. The antimicrobial finishes prevent microbial attacks (fungi, bacteria, mould, mildew or algae) on textiles, thus enabling them to maintain their functional, aesthetic or hygienic values [1]. The degree of microbial deterioration depends on the fibres (physical and chemical properties), the type of micro-organisms and environmental conditions (temperature, moisture, $\mathrm{pH}$ and oxygen). The antimicrobials used can either be biocidal; this is when the concentration of the applied agent is higher than the lethal concentration, thus when microbes come into contact with the fibres they are killed; or biostatic; the concentration of applied agent is below the lethal concentration and only inhibits microbial reproduction and growth. The mechanisms by which antimicrobial agents operate are also important. Those agents that are not chemically bonded to the textile fibres' antimicrobial activities gradually reduce moisture release into the environment. Due to leaching in the presence of moisture/water, the effectiveness of such agents reduces. On the other hand those agents that are chemically bonded to the textile materials kill micro-organisms on contact and their durabilities are higher comparatively [2].

The soil burial test is performed according to BS 6085:1992 (equivalent to Kenya Standard KS 1328-1) [3]. The principle of this test is that the test specimen is subjected to microbiological attack by soil burial and the loss in performance (strength) caused by exposure assessed according to the test standard ISO 5081, a method for determining the breaking load-strip methods of woven fabrics (Equivalent to
KS 08-119) [4]. The time of exposure for textiles during the test is usually 14 days for non-coated cellulosic textiles and 28 days for coated cellulosic textiles. These durations are too long, given that at this time and age manufacturers and scientists want to obtain test results as quickly and efficiently as possible. Taking a case study concerning the Kenya Bureau of Standards (KEBS), the national standards body in Kenya, most samples submitted for testing are usually urgent and clients (manufacturers and researchers) expect a report within 5-7 days. This is because the test results are needed for quick decision-making. Therefore, for samples that need to undergo the soil burial test (which takes an average of 14-28 days); the clients forego this test due to the long duration of testing. This presents a major drawback for the clients as they are unable to obtain the results of such a crucial test or they may obtain them but not in sufficient time to suit their decision- making processes. It also creates a risk to the consumers of such products that have not undergone all the required tests for performance specifications.

Apart from the textile material, in this case we limited ourselves to canvas material [5] the degradation of a textile material also depends on the amounts and activities of micro-organisms within the soil. Some of the conditions that affect micro-organisms during laboratory cultivation as well as in the soil are: amount and type of nutrient, available moisture, degree of aeration, temperature, $\mathrm{pH}$, and other practices and occurrences (for example the addition of manure) [6-8]. Simple manipulations of the properties of the soil can therefore lead to increased microbial activity. One simple way of manipulating soil properties is by the addition of manure. Manure is an organic matter used as organic fertilizer in agriculture. Manures contribute to the fertility of the soil by adding organic matter and nutrients. Besides providing valuable macro and micro-nutrients to the soil, manure supplies organic matter for improving the soil's physical and chemical properties. It also increases the infiltration of water and enhances 
the retention of nutrients, reduces wind and water erosion, and promotes the growths of beneficial organisms. The main classes of manure are; animal, compost and plant manure. When considering animal manure, chicken manure has a high concentration of nutrients [7].

This research work investigated various methods of improving the soil burial test by cultivating soil samples for increasing microbial activity and exposing textile samples to these cultivated soils for determining a reduction in the strength of a canvas material during the burial test.

\section{Experimental}

\subsection{Materials}

Canvas material composed of $100 \%$ cotton, average mass per unit area; $460.9 \mathrm{~g} / \mathrm{m}^{2}, 21 \mathrm{ends} / \mathrm{cm}$ and 11 picks/cm was purchased from a local supplier. Free garden soil was obtained from a suitable location and the top soil (about $15 \mathrm{~cm}$ from the soil surface) extracted [9]. The soil was found to have a moisture content of $24.58 \%$ and $\mathrm{pH}$ of 6.33 . Plastic containers measuring $320 \mathrm{~mm} \times 240 \mathrm{~mm} \times 150 \mathrm{~mm}$ were also purchased from local suppliers, and used as soil receptacles. Cow and chicken manure were collected from the local farmers and the potato peelings collected from the local markets.

\subsection{Samples' preparations}

Canvas fabric specimens of lengths $200 \mathrm{~mm}$ and width $50 \mathrm{~mm}$ were prepared according to ISO 5081 for both the warp and weft directions. Garden soil was placed under room conditions for 24 hours before determining its moisture content and $\mathrm{pH}$.

\subsection{Burial procedure}

Prior to burial, the average breaking loads of the canvas specimens, both warp and weft, were determined according to ISO 5081. Soil samples to depths of $15 \mathrm{~mm}$ were placed in the soil receptacles. Canvas specimens (warp and weft directions) were then placed flat on the container. Soil was then added to cover the canvas specimens, as shown in (Fig. 1). The containers with the buried specimens were then placed under room conditions for 14 days. After 14 days of being buried the soils affecting the canvases were carefully removed from the specimens by brushing and then gently rinsing the specimens in water. The specimens were then sterilised by soaking them in $70 \%$ ethanol at room temperature for 4 hours, dried and then conditioned within a standard atmosphere for the testing of textiles i.e. temperature $22^{\circ} \mathrm{C}$ and relative humidity of $65 \%$.

The strength losses of the canvas specimens were then assessed by determining the breaking loads of the buried specimens and comparing them with the breaking loads of the non-buried specimens.

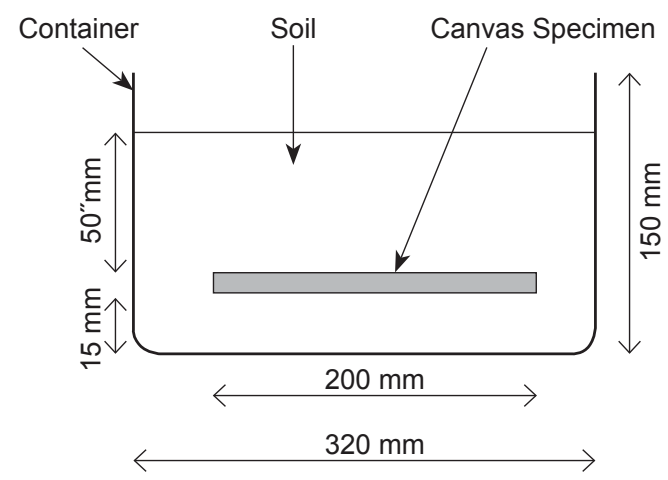

Figure 1: The burial test equipment

\subsection{Soil preparation}

Soil samples from the same batch were cultivated using three different methods. Cow manure, chicken manure, and potato peelings were used as the microbial growth enhancers during soil cultivation. The process of cultivation involved mixing the soil

Table 1: Soil samples used for burial test

\begin{tabular}{|c|l|c|}
\hline SN & \multicolumn{1}{|c|}{ Soil type } & $\begin{array}{c}\text { Addition } \\
\text { of water }\end{array}$ \\
\hline 1 & Non-cultivated soil & No \\
\hline 2 & Non-cultivated soil & Yes \\
\hline 3 & $\begin{array}{l}\text { Cultivated soil with cow } \\
\text { manure }\end{array}$ & No \\
\hline 4 & $\begin{array}{l}\text { Cultivated soil with cow } \\
\text { manure }\end{array}$ & No \\
\hline 5 & $\begin{array}{l}\text { Cultivated soil with } \\
\text { chicken manure }\end{array}$ & $\begin{array}{l}\text { Yes } \\
\text { chicken manure }\end{array}$ \\
\hline 7 & $\begin{array}{l}\text { Cultivated soil with } \\
\text { potato peelings }\end{array}$ & Yes \\
\hline 8 & $\begin{array}{l}\text { Cultivated soil with } \\
\text { potato peelings }\end{array}$ \\
\hline
\end{tabular}


samples with the required microbial growth enhancers at ratios of 2:1 (soil: microbial growth enhancers). The three types of cultivated soil samples were then left under room conditions for 24 hours. During the burial tests, the soil samples were prepared as shown in Table 1. Water was added to some of the soil samples (see Table 1) according to the following procedure; $500 \mathrm{ml}$ of water on the first day of the burial test and $200 \mathrm{ml}$ daily on subsequent days for the entire 14 day period.

\subsection{Methods}

The breaking load was determined in accordance with the method of determining the breaking loads (strip method) of the woven fabrics; ISO 5081. The average breaking load was calculated in both the warp and weft-directions. The speed of testing on the universal tensile testing machine was $100 \mathrm{~m} / \mathrm{min}$. The change in strength was calculated based on the original breaking load of the canvas before burial, as expressed in equation 1;

Change in strength due to burial test $=$

$100-\frac{\text { Breaking load after burial }}{\text { Breaking load before burial }}$

After assessments of the changes in strengths due to the burial test, a reduction factor for each cultivated soil sample was calculated using equation 2 . The reduction factor gave the factor with which the burial duration could be reduced.

Reduction factor $=$

Change in strength in cultivated soil Change in strength in original soil

\section{Results and Discussion}

\subsection{Strength loss}

The results for the breaking loads of the non-buried samples, samples buried in non-cultivated soils, and those samples buried in cultivated soils with and without water addition are summarised in Table 2 . For comparison, the results of strength loss due to the burial test obtained from different burial conditions for both warp and weft directions can be represented as in (Fig. 2).

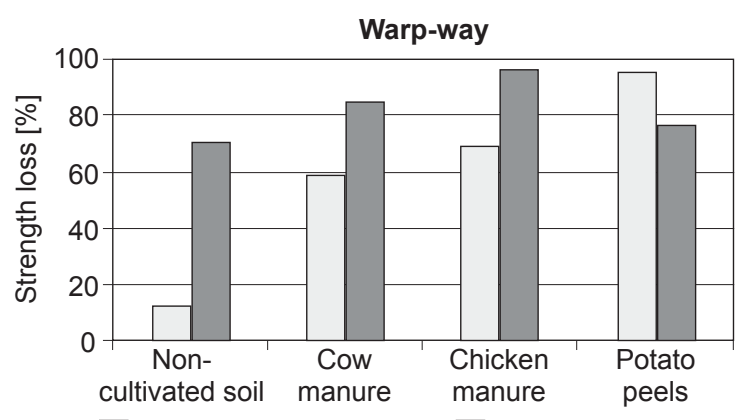

Without water addition

With water addition

Weft-way

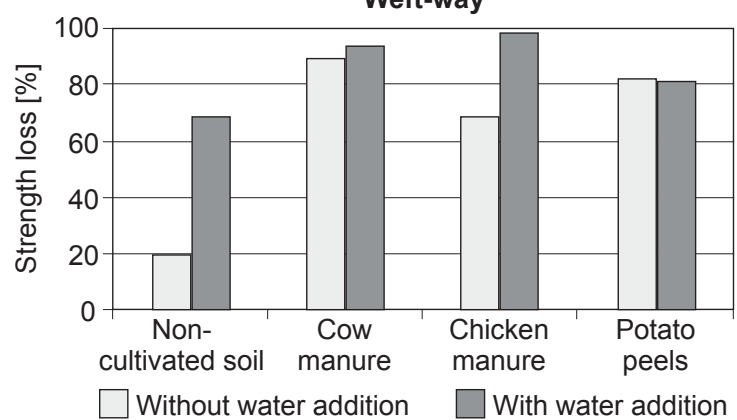

Figure 2: Warp and weft-way strength loss due to burial test

Table 2: Breaking load and strength loss of canvas material under different loads

\begin{tabular}{|l|c|c|c|c|}
\hline \multirow{2}{*}{} & \multicolumn{2}{|c|}{ Average breaking load [N] } & \multicolumn{2}{c|}{ Strength loss [\%] } \\
\cline { 2 - 4 } & Warp-way & Weft-way & Warp-way & Weft-way \\
\hline Non-buried canvas & 1447.84 & 920.42 & - & - \\
\hline Soil & 1279.7 & 735.1 & 11.63 & 20.13 \\
\hline Soil \& cow manure & 596.76 & 105.4 & 58.78 & 88.55 \\
\hline Soil \& chicken manure & 435.06 & 286.12 & 69.95 & 68.91 \\
\hline Soil \& potato peels & 66.16 & 165.14 & 95.43 & 82.06 \\
\hline Soil \& water & 428.46 & 282.55 & 70.41 & 69.30 \\
\hline Soil, cow manure \& water & 220.18 & 61.80 & 84.79 & 93.29 \\
\hline Soil, chicken manure \& water & 49.60 & 29.04 & 96.57 & 97.99 \\
\hline Soil, potato peels \& water & 328.24 & 170.14 & 77.33 & 81.52 \\
\hline
\end{tabular}


From the above results, it can be seen that for burial tests done using the original soil (non-cultivated soil) without water addition, the strength loss after 14 days was low when compared to other soil variations. This can be attributed to lower microbial activity in the soil. The micro-organism activity could have been adversely affected by the fact that the containers were not covered hence there was moisture loss during the 14 day test period. For burials in the original soil (non-cultivated soil) with water addition, the microbial activities increased and this was shown by the significant increases in strength losses of the canvases. The increase in microbial activity was due to the availability of water in the soil that increased microbial mobility and nutrient diffusion [9]. The loss in strength after burial of cotton strips have been shown to be an indirect but accurate way of estimating the increase in soil microbial activity [10].

For burials done in soil cultivated using cow manure without water addition, there had been increased microbial activities when compared to the non-cultivated soil without water addition. This resulted in increased strength losses. This indicates that cow manure offers nutrients to the micro-organisms. When water was added to this cultivated soil, the microbial activities further increased, leading to further fabric strength losses. Therefore water addition to the soil cultivated with cow manure had led to increased microbial activity.

The soil cultivated with chicken manure showed a similar trend to the soil cultivated with cow manure. This was expected due to an increase in soil nutrients. When water was added to the cultivated soil, the strength losses greatly increased indicating that the microbial activities had increased significantly. The increases in microbial activities for the soils cultivated using chicken manure with the addition of water, showed the highest strength loss. This could be because chicken manure possesses 2 to 3 times as much nitrogen, 3-5 times as much phosphorus while potassium is the same when compared to other farm manures. In addition to this, chicken manure is also a good soil conditioner and increases the soils' moisture and nutrient holding capacities [11]. Therefore, soils cultivated with chicken manure with water addition had better moisture and nutrient holding capacities leading to the highest microbial activities amongst the cultivated soil. This finding was consistent with Ruschmeyer et al [12], who reported that an increase of nitrogen in soils increases cellulose decomposition.
Samples buried in soil cultivated using potato peelings also showed a significant increase in strength losses when compared to non-cultivated soil without water addition. For this soil though, the addition of water decreased the strength loss indicating that microbial activities had decreased with water addition. It can therefore be concluded that for soils cultivated with potato peelings, microbial activity is high at low moisture levels.

\subsection{Reduction factors}

The reduction factor for warp direction strength loss was done to determine the extent by which the burial duration may be reduced, using equation 2 . The results of the reduction factors for warp-direction are given in Table 3. Similarly the weft direction strength losses could also have been used to determine the strength loss but to avoid repetition only the warpdirection reduction factors were considered.

\section{Table 3: Reduction factors for various cultivated soils}

\begin{tabular}{|l|c|}
\hline \multicolumn{1}{|c|}{ Soil used for burial } & $\begin{array}{c}\text { Reduction } \\
\text { factor }\end{array}$ \\
\hline Soil and water & 6.06 \\
\hline Soil and cow manure & 5.06 \\
\hline Soil and chicken manure & 6.02 \\
\hline Soil and potato peels & 8.21 \\
\hline Soil, cow manure and water & 7.30 \\
\hline Soil, chicken manure and water & 8.32 \\
\hline Soil, potato peels and water & 6.66 \\
\hline
\end{tabular}

According to the reduction factors, it is evident that the cultivated soil samples gave significant reduction factors indicating that the cultivated soils had higher or increased microbial activities than the original soil. From Table 3, it can be deduced that cultivated soil using chicken manure with water addition gave the highest reduction factor of 8.32. It is also obvious that burial in cultivated or modified soils yielded better results than that of original soil regarding the soil burial standard. Even when using the original soil with water treatment addition led to a reduction factor of over 6 . In order to obtain an estimated reduced exposure time, using the cultivated soils, the number of days can be divided by the reduction factors of each soil sample. Taking an example from soil cultivated with chicken manure with water addition, the time of exposure of coated textiles during the burial test would reduce from 28 days to less than a week and 14 days 
to less than 2 days. This is not the case, however, because the above-mentioned approach assumes that microbial deterioration occurs linearly. It has been shown that during decomposition, bacteria initiate the process of decomposition with fungi coming into play in the later stages of decomposition [5]. It is also known that fungi attack fibres from the inside moving outwards, while bacteria attack fibres from the fibres' surfaces moving towards the inner parts of the fibre [13]. Cellulose decomposition is also a chemical process involving breakdown of cellulose by microbial enzymes [8]. For the above reasons, therefore, it can be noted that decomposition is a combination of complex mechanisms and thus cannot be treated as a linear process. Thus the burial times for coated textiles can be set at 14 days and non-coated textiles 7 days. This would leave enough room for the invariabilities and complexities of the decomposition process.

\section{Conclusion}

The Soil burial test as per the BS 6085: 1992 standard has a very long burial duration and this causes many to ignore this important test. A reduction in time during the soil burial test is therefore crucial and according to the results obtained in this research work, modification of the soil could be done to reduce the burial test time. This research work used three types of nutrients (cow manure, chicken manure, and potato peelings) and the controlled additions of water, to study the reducing of the strengths of the canvas material. The results obtained during this research work indicated that the addition of water (in a controlled manner) can lead to changes of $10 \%$ to $90 \%$ in the strengths of the buried canvas materials, for the different types of manure, whilst the addition of water did not seem to show a similar trend when considering potato peelings. When considering the different types of manure (with water addition) there were strength losses of $70 \%, 80 \%$ and $90 \%$ in the warp direction, whilst the weft direction losses of strength of $70 \%$, $90 \%$, and $90 \%$ were recorded. A strength reduction formulae where the reduction in strength compared to the non-treated soil (without water), indicated that chicken manure (with the addition of water) can produce a strength reduction factor of 8.32 , whilst the non-cultivated soil (with the addition of water) gave a strength reduction factor of 6 . It is recommended that further research be done, and a direct method be adopted for measuring the microbial activities.

\section{References}

1. ELSHAFEI, Ali and EL-ZANFALY, H.T. Application of antimicrobials in the development of textiles. Asian Journal of Applied Science, 2011, 4, 585-595, doi: 10.3923/ajaps.2011.585.595.

2. TOMŠIČ, Brigita, KLEMENČIČ, Danijela, SIMONČIČ, Barbara and OREL, Boris. Influence of antimicrobial finishes on the biodeterioration of cotton and cotton/polyester fabrics: leaching versus bio-barrier formation. Polymer Degradation and Stability, 2011, 96(7), 1286-1296, doi:10.1016/j.polymdegradstab.2011.04.004.

3. BS 6085 Methods for determination of the resistance of textiles to microbiological deterioration. British Standard Institute. London, 1992.

4. ISO 5081 Textiles - Woven fabrics - Determination of breaking strength and elongation (Strip method). International Organisation for Standardization, 1977.

5. Canvas [online], [accessed 11. 3. 2014]. Available on World Wide Web: <http://en.wikipedia. org/wiki/Canvas>.

6. PELCZAR, Micheal Joseph, CHIN SUN CHAN, Eddie and KRIEG, Noel R. Microbiology: Concepts and Applications. $1^{\text {st }}$ ed. New York: McGraw-Hill, 1993.

7. Manure. [online], [accessed 11. 3. 2014]. Available on World Wide Web: <http://www.wikipedia. com/manure $>$.

8. CHANDRA, R. and RUSTGI, R. Biodegradable polymers. Progress in Polymer Science, 1998, 23(7), 1273-1335, doi:10.1016/S0079-6700(97)00039-7.

9. COYNE, Mark S. Soil microbiology: An exploratory approach. Albany et al.: Delmar Publishers, 1999.

10. LATTER, P. M., BANCROFT, G. and GILLESPIE, J. Technical aspects of the cotton strip assay in soils. International Biodeterioration, 1988, 24(1), 25-47, doi:10.1016/0265-3036(88)90073-5.

11. Chicken manure. [online], [accessed 11. 3. 2014]. Available on World Wide Web: <http://www.ctahr. hawaii.edu/oc/freepubs/pdf/GHGS-02.pdf >

12. RUSCHMEYER, O. R. and SCHMIDT, E. L. Cellulose Decomposition in soil burial beds: II. Cellulolytic activity as influenced by alteration of soil properties. Applied Microbiology, 1958, 6(2), 115.

13. CLARKE, Antony J. Biodegradation of cellulose: enzymology and biotechnology. Basel: Technomic Publishing, 1996. 